\title{
Approaches to the solving of ethnic issues during the interwar Czechoslovakia and Hungary
}

Komárno, Slovakia, 24 - 25 April 2014

Between 24 - 25 of April 2014 at the University of János Seley in Komárno there took place an international scientific conference named "Approaches to the solving of ethnic issues during the interwar Czechoslovakia and Hungary". Organizers were the Cathedra of History of Pedagogic Faculty of the University of Janos Seley in Komárno and the Institute of Social Sciences in Košice. The conference was enacted in the frame of the project VEGA Czechoslovak Republic and Hungarian minority in Slovakia (1930-1938). The program of the scientific conference was divided into two days and content into five panels. Presented were 20 papers, as well as participants of Slovak nationality, papers were also presented by Hungarian and Czech participants and one German scientist.

The conference was started by a speech given by the pro-rector for science, research and accreditation, Juhász György from the University J. Seley (UJS). The first participant, László Szarka from the Cathedra of History of Pedagogic Faculty of UJS in Komárno, in frame of the first panel, named Various Aspects of the Status of Hungarians in Czechoslovakia, presented a paper named "United Hungarian Party and the conception of minority block in the time of Czechoslovak crisis". The following paper was presented by Milan Olejník from the Institute of Social Sciences, named "Hungarian community on the eve of elections into the National Assembly in year 1929". The next paper, named "Hungarian schools in Košice (1918 - 1938)" was presented by Soňa Gabzdilová from the Institute of Social Sciences SAS. Mária Ďurkovská from the Institute of Social Sciences SAS read a paper named "Hungarians in Košice in the context of censuses of population in years 1921 and 1930". Next followed a concise, but dynamic discussion, after which, in frame of the second panel, named Situation of non-traditional minorities in the First Czechoslovak Republic, Anna Jurova from the Institute of Social Sciences SAS read a paper named "The Gypsy question in the First CSR". There followed a presentation by Stanislav Konečný from the Institute of Social Sciences SAS, who read a paper named "Ruthenian minority in Czechoslovakia and the question of autonomy". The next speaker, Peter Švorc from the Institute of History of Prešov University in Prešov presented a paper named "Jews in Eastern Slovakia after state turnover 1918 - Jewish, Hungarian or Czechoslovak identity?" After a break, the third panel, named Various aspects of minority policy was begun by Eva Irmanová from the Historic 
Institute of Sciences of the Czech Republic, who read a paper about Masaryk's conception of liberty program and the struggle of the Czechoslovak government for the gaining of Slovakia. The next paper, named "Minority activism and conception of national state" was presented by Attila Simon from the Cathedra of History of the Pedagogic Faculty of UJS in Komárno. Next referee was Martin Furmanik from the Institute of Social Sciences SAS, presenting a paper name "Attitude of the pro-Hungarian oriented population in Spis toward the foundation of the CSR". The first day of the conference was closed by Miroslav Lacko from the Institute of Contemporary History of Academy of Sciences of the Czech Republic, who presented a paper named "Repatriation of Czechs and Slovaks into the CSR via Czechoslovak institutions and its impact upon the nationality issue". The first day of the conference ended with social intercourse of participants on the premises of the Philosophic Faculty of UJS.

Next day a fourth panel, named Local and European aspects of the nationality question was enacted by Veronika Gayer from the Institute for Research of Minorities of the Hungarian Academy of Sciences, who presented a paper named "Local or Hungarian interest. Activities of Karol Flórián, mayor of Prešov (1923 - 1927)". Following referees were Robert Arpás from the Historical Institute of SAS in Bratislava ("Autonomy via HSL'S - a step to totality"); Ildikó Bajcsi from the Cathedra of History of the Faculty of Philosophy of University of Karoly Esterházy in Eger ("Generation Conflicts in the Ranks of the Hungarian Élite in the First Czechoslovakian Republic"); Andrej Tóth from the Faculty of Public Politics of the Silesian University in Opava ("In Regard to some Aspects of Hungarian Minority Status"); István Janek from the Research Center of Humanities of the Hungarian Academy of Sciences in Budapest, Martin Zückert from Collegium Carolinum in Munich ("Deliberations in regard to interwar Czechoslovakia"); László Bóna from the Cathedra of History, Faculty of Philosophy of the University of Karoly Esterházy in Eger ("Assimilation of Hungarians in Slovak Cities in the example of Banská Bystrica"); Péter Bencsik from Cathedra of Modern European History of the Faculty of Philosophy, University in Szeged ("Representation of Hungarian Minority Interests in the National Assembly") and lastly a paper presented by Arpád Popély from the Pedadogic Faculty of JSU in Komarno ("Nationalities in Slovakia and Elections into the Assembly of the Slovak Country in December 1938").

The broad scope of the papers contributed to a lively exchange of views and information offered by participants. Contemplated were possibilities of collective projects in future. Papers presented during the conference will be published in abridged form.

Milan OLEJNíK

Institute of Social Sciences Slovak Academy of Sciences, Košice 